\title{
IJBF DO EXCHANGE RATES AFFECT THE STOCK PERFORMANCE OF AUSTRALIAN BANKS?
}

\author{
Jing Chi, David Tripe and Martin Young \\ Massey University, New Zealand
}

\begin{abstract}
It is expected that banks with significant foreign business should be impacted by relative changes in the currency values of the foreign countries where they do business. Using data from January 1997 to March 2007, this study explored this relationship for the four major Australian banks. Contrary to expectations, no significant relationships between Australian bank stock returns and foreign exchange rates were found, raising questions as to the efficiency of stock markets in recognising banks' foreign exchange exposures arising from their offshore assets and business.
\end{abstract}

Keywords: Exchange rates, Offshore assets, Stock returns, Australia, Bank international expansion.

JEL classification: G12, G21.

\section{Introduction}

A number of theories has been proposed as to why banks should expand internationally, although all of these, ultimately, relate to banks' ability to earn profits from doing so. Major theories to explain international expansion, many of which also apply to multinational firms more generally, include the industrial organization theory, the comparative advantage theory, the international investment theory, portfolio theory, the internalisation theory and the eclectic theory.

The industrial organisation theory has a number of different strands, including banks following their customers into foreign markets, higher concentration in the home country market providing higher profits to support expansion, greater strength or importance of the home country currency and a desire to secure (retail) deposits in the host country. The comparative advantage theory proposes that banks expand from countries with a comparative advantage in the supply of banking services. International investment theory is based on 
the idea that banks expand internationally in order to exploit or avoid market externalities, while portfolio theory argues that international expansion is a risk diversification decision. Internalisation theory proposes that banking firms expand internationally to get around imperfections in, for example, financial market information, and generate an internal advantage by retaining firmspecific advantages for their own benefit. The eclectic theory combines a number of strands, largely from the internalisation theories: these are ownership-specific advantages, internalisation specific advantages and location-specific variables. ${ }^{1}$

Within this range of options, relatively little attention has been given to portfolio theory, which could be used to argue that banks ought to expand internationally to reduce the risks of investing solely in their home markets. The risks that might be reduced include not only the economic conditions applying in particular countries, which have direct effects on bank performance, but also the values of currencies of the countries in which multinational banks do business. With the equity of larger banks now being traded on international markets, a concentration of assets in only one currency would expose shareholders to risks in respect of that single currency. This might be less of an issue for banks whose home markets are larger zones such as the United States or the Eurozone, but - it will be more important for banks from smaller (and more volatile) currency areas such as Australia.

Grosse and Goldberg (1991) found that banks from countries considered risky were more likely to have a foreign office, but an alternative perspective has been that countries can diversify their loan portfolios internationally without an extensive network of foreign offices (although a bank's lending portfolio might then be limited to low-margin, wholesale business). Other studies have considered exchange rates as a factor in banks' foreign investment decisions, but the focus of these has often been on the issue of whether an investment is likely to generate a foreign exchange gain or a loss (e.g. Hultman and McGee, 1989; Moshirian and Pham, 1999; Moshirian, 2001). Relatively little attention has been given to looking at internationally-active banks' assets as a portfolio, with sub-portfolios in different countries exposed to different risks and returns.

This paper attempts to fill some of the gap in the exploration of the portfolio theory of the international expansion of banks by looking at the four major Australian banks, each of which has significant operations outside Australia. The specific focus is on the impact of changes in the exchange rate of the Australian dollar relative to the currencies of the main countries into which these major Australian banks have expanded their operations. The effect was measured in terms of the effect on stock returns for those Australian banks; the sample period was from 1 January 1997 to 31 March 2007 and the methodology employed is the capital market method. Surprisingly, we find no significant foreign exchange impact on the four major Australian banks' stock returns, or

${ }^{1}$ This summary of the theories and their strengths and weaknesses is very brief. For a more extensive review, please refer to Cho (1985), Williams (1997), and Tripe and Matthews (2003). 
on the stock returns of the five Australian regional banks whose focus is on the domestic market only. Questions are then raised as to the efficiency of stock markets in recognising banks' foreign exchange exposures arising from their overseas assets and business.

The rest of the paper is structured as follows. The next section provides some detail on the international operations of the major Australian banks and their history. The third section outlines the key hypothesis that will be explored in this study, while section 4 introduces the data that are used for the analysis. Section 5 reports and reviews the results and discusses their implications, while section 6 concludes and identifies issues for further research.

\section{The Major Australian Banks and Their International Expansion}

The Australian banking market is dominated by four major banks, which together control around $66 \%$ of the market by assets (as at January 2007). These are the Australia and New Zealand Banking Group Limited (ANZ), Commonwealth Bank of Australia (CBA), National Australia Bank (NAB), and the Westpac Banking Corporation (Westpac). Each of these banks is listed on the Australian Securities Exchange (ASX), where they are among the largest listed companies, and each of them has both retail and other banking business outside Australia. ${ }^{2}$ These banks are also significant in international terms, ranked at 59, 60, 38 and 71 respectively by Tier One capital in the Banker magazine's 2007 listing.

The CBA is the youngest of these banks, originally established as a government-owned institution in 1911, but fully privatised since 1996. Like all the major Australian banks, it has offices in the major financial centres of London, New York, Tokyo, Hong Kong and Singapore. It expanded into New Zealand with the acquisition of $75 \%$ of ASB Bank in 1989, with the remaining $25 \%$ acquired in 2000. Its other significant international expansion has been into Fiji, where it acquired a business with the acquisition of Colonial Limited (an Australian bancassurance group) in 2000. There are some small operations in other countries, but the New Zealand business is the largest outside Australia. The trend in all banks' international activities is shown in Figure 1.

Westpac is the longest established of the Australian banks, having been originally established as the Bank of New South Wales in 1817. It has had business in New Zealand since the Bank of New South Wales' acquisition of the New Zealand business of Oriental bank in 1861, with the New Zealand business increasing in importance following the acquisition of Trust Bank New Zealand in 1996. Westpac embarked on an ambitious plan to try and turn itself in to a major multinational bank in the late 1980s, but the somewhat disappointing ensuing

${ }^{2}$ The following summary of Australian banks and their international operations is relatively brief. For a more extensive discussion, please see Tripe and Matthews (2003) and Wilkins (2003). 
performance and lending losses in its home market forced the abandonment of this strategy. ${ }^{3}$ Its international activities now comprise the standard network of offices in major financial centres and business in New Zealand and a number of smaller countries in the Pacific.

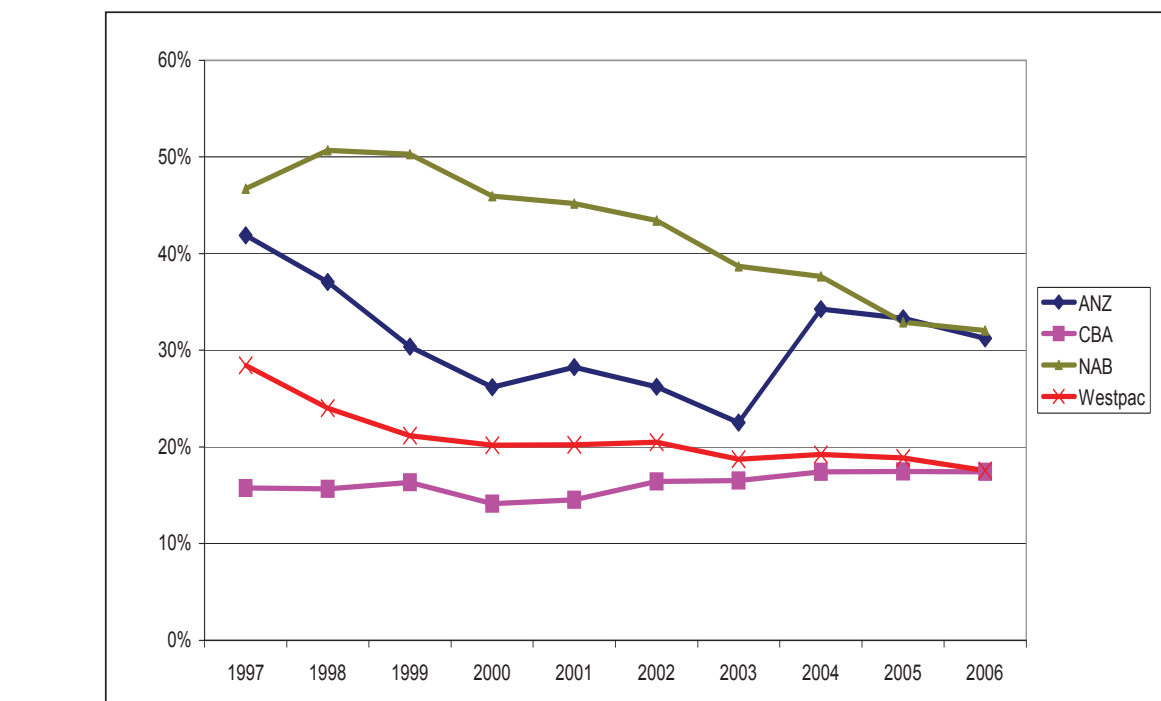

Figure 1. Percentage of Assets Outside Australia - Major Australian Banks

NAB was originally among the more Australian focused of the major banks, but in 1987 it purchased a network of retail banks in Scotland and Ireland. This was followed by further expansion by acquisition into the United Kingdom, New Zealand and the United States, although in more recent years it has sold both its United States business and that in Ireland. In addition to its network of offices in international financial centres, it thus now has significant business in England and Scotland (trading as the Clydesdale and Yorkshire Banks) and New Zealand (where it trades as Bank of New Zealand).

Some arguments have been put forward to suggest that a major benefit of the NAB's expansion into the UK market was to relieve the bank from the consequences of its previous concentration of exposures in the Australian banking market (Robinson, 1990), consistent with the portfolio theory. For the period from 1988 to 2000, the correlation coefficient between the returns on assets for the Australian and UK businesses was 0.22, which does lend support to that portfolio effect argument.

ANZ is now the major Australian bank with the greatest proportion of its business in New Zealand. All of its major constituent banks, the Union Bank,

${ }^{3}$ For a more extensive discussion of these events, refer to Carew (1997). 
the Bank of Australasia and the English Scottish \& Australian Bank (ES\&A), started life as British overseas banks, with both the Union Bank and the Bank of Australasia having operated in New Zealand. The bank sought to increase its international involvement still further in 1984 with the acquisition of Grindlays, although this was not wholly successful, and after successive scaling back of the Grindlays network, the remains of the bank were sold in 2000. In 2003, the ANZ increased the proportion of its business in New Zealand through the acquisition of the National Bank of New Zealand. Its international network now comprises the standard network of offices in major financial centres, its New Zealand business (comprising nearly $25 \%$ of assets as at 30 September 2006), and in the smaller countries of the Pacific and through a number of offices in East and South-East Asia.

The position of the preceding big four banks contrasts with that of the other Australian banks listed on the ASX. These other five so-called regional banks, Adelaide Bank (ADB), Bank of Queensland (BOQ), Bendigo Bank (BEN), St George Bank (SGB) and Suncorp Metway (SUN), are much smaller and do not, in general, have any non-Australian business. We would thus not expect these banks to show the same sensitivity to exchange rates for the Australian dollar as the big four, and they have been included in this research in the expectation that there should be different effects for these banks. ${ }^{4}$

Against this background, the next two sections of the paper describe the methodology used to explore the significance of any portfolio effects in the international expansion of the Australian banks, and look at the data used to undertake this analysis.

\section{Methodology}

\section{Hypotheses}

There are in fact three ways in which banks can be exposed to changes in exchange rates. It is common to recognise the short run exposure that arises from foreign exchange trading, and the medium term exposure arising from mismatches between the currencies in which a bank's assets and liabilities are denominated. There is also, however, a longer-term exposure, which might be related to a translation exposure that arises from banks' investments in the banking business in other countries where different currencies are used.

In the case of the major Australian banks, exposures from foreign exchange trading and from asset and liability mismatches are small. Although the banks raise significant portions of their funding in international markets, the vast bulk of this is hedged into Australian dollars (Staff, 2000; 2002). Value-at-risk from

\footnotetext{
${ }^{4}$ Macquarie Bank is also listed on the Australian Securities Exchange, but its business is primarily in investment banking, and bears only limited resemblance to the banks included in this study.
} 
trading exposures is also very small (Staff, 2000). The Reserve Bank of Australia further notes that the main foreign exchange exposure of banks arises on the asset side from their equity investment in offshore operations (Staff, 2002). Becker et al. (2005) showed that banks continued to have relatively low levels of foreign currency exposure, other than in respect of their offshore business.

The general principle in this research was to perceive banks as comprising a portfolio of assets. Our proposition is that the market performance of banks should respond to changes in the value of their underlying assets making up these portfolios. If these underlying assets are held in different currencies, changes in the values of these currencies ought to impact on the market value of the banks, except insofar as the net foreign currency position relative to those assets is hedged into Australian dollars. Such hedging would indicate that the bank did not want the relative currency exposures. While the banks we considered primarily in this study do not state precisely their hedging policy in relation to the value of assets held offshore, the common practice is to hedge offshore profits but not the offshore assets themselves.

There are thus alternative hypotheses that may apply to the different scenarios. It may be that banks do not hedge their currency exposures, and that markets are efficient, in which case a strengthening of that foreign currency relative to the Australian dollar would result in an increase in the bank's relative share price (reflected in positive stock returns). Alternatively, if banks hedge their foreign currency positions, we would expect no relationship to be evident. The third possibility is that share markets fail to adequately reflect information about the currencies to which the banks are exposed: this is not the expected outcome, but it is noted that relatively little attention is given to the effects of

exchange rate changes in the discussion of bank performance. ${ }^{5}$

In our study, we use stock returns to evaluate the four major Australian banks, with five regional banks included to provide a comparison (and for which different results might be expected). We hypothesize that three major exchange rates, namely US dollar (USD) to Australian dollar (AUD), Sterling Pound (GBP) to Australian dollar and New Zealand dollar (NZD) to Australian dollar, would have an impact on the bank's stock performance. The higher the exchange rates, the stronger the Australian dollar is and the weaker the foreign currencies are. The weak foreign currencies will reduce the value of the overseas assets of the Australian banks. Other things being equal and if the banks do not hedge their foreign exchange exposure, we expect banks' stock returns to be impacted negatively when exchange rates increase, due to the high proportion of banks' foreign assets.

In our study, we also consider the impact from the market index returns and interest rate and real GDP differentials between two countries on the bank stock returns. Market index returns are considered directly, but interest rate and GDP differentials are considered through their expected impact on the exchange rate.

\footnotetext{
${ }^{5} \mathrm{An}$ exception to this is the case of Westpac, where exchange rate differences relative to the New Zealand dollar in particular are identified as impacting on reported results.
} 


\section{Data}

In this study, we focused on the sample of the four major Australian banks (ANZ, NAB, CBA and WBC) and use quarterly data from 1 January 1997 to 31 March 2007. We also studied five regional Australia banks as a comparison with the four major banks, since the five regional banks have little overseas assets in comparison with the major four. We start our sample period in January 1997 to avoid possible problems caused by two significant events that took place in 1996, namely Westpac's acquisition of a major New Zealand asset, Trust Bank New Zealand, and the completion of privatisation of CBA.

The stock returns of nine banks, the market index returns (ASX200), foreign exchange rates between the United States dollar, Pound Sterling, New Zealand dollar and Australian dollar, three month inter-bank rates of the US, Britain, New Zealand and Australia, and real GDP of these four countries are collected from the Datastream. The summary statistics for our data are provided in Table 1.

\section{Table 1}

Statistical Summary of Variables in the Study

\begin{tabular}{lrrrrr}
\hline & Mean & Median & SD & \multicolumn{1}{c}{ Min } & Max \\
\hline ADB & 0.037 & 0.027 & 0.074 & -0.083 & 0.194 \\
BOQ & 0.036 & 0.040 & 0.078 & -0.132 & 0.169 \\
SGB & 0.048 & 0.038 & 0.068 & -0.056 & 0.177 \\
BEN & 0.041 & 0.038 & 0.108 & -0.207 & 0.254 \\
SUN & 0.052 & 0.071 & 0.084 & -0.152 & 0.235 \\
ANZ & 0.045 & 0.045 & 0.085 & -0.140 & 0.282 \\
NAB & 0.035 & 0.047 & 0.080 & -0.219 & 0.241 \\
CBA & 0.047 & 0.054 & 0.076 & -0.160 & 0.185 \\
WBC & 0.041 & 0.046 & 0.079 & -0.138 & 0.248 \\
ASX200 & 0.032 & 0.033 & 0.052 & -0.090 & 0.109 \\
AUD/NZD & 0.858 & 0.864 & 0.045 & 0.770 & 0.938 \\
AUD/GBP & 2.537 & 2.527 & 0.200 & 2.076 & 2.882 \\
AUD/USD & 1.547 & 1.532 & 0.232 & 1.280 & 1.984 \\
Inter-bank (NZ-A) & 0.998 & 1.010 & 1.070 & -0.620 & 3.960 \\
Inter-bank (US-A) & -1.380 & -1.069 & 1.795 & -4.820 & 0.910 \\
Inter-bank (UK-A) & -0.110 & -0.305 & 1.308 & -1.794 & 2.611 \\
Real GDP (NZ/A) & 0.120 & 0.120 & 0.007 & 0.108 & 0.132 \\
Real GDP (US/A) & 19.137 & 19.010 & 2.931 & 15.510 & 24.766 \\
Real GDP (UK/A) & 3.340 & 3.307 & 0.267 & 2.824 & 3.801 \\
\hline
\end{tabular}

Note: The variables include the stock returns of four major Australian banks (ANZ, $\mathrm{NAB}, \mathrm{CBA}$ and Westpac) and five Australian regional banks (Adelaide Bank, Bank of Queensland, Bendigo Bank, St George Bank, and Suncorp-Metway); the ASX200 market index returns; three exchange rates (AUD/USD, AUD/GBP, and AUD/NZD); the difference between the three month inter-bank rates of New Zealand, US, UK and Australia; and the ratio of the real GDP of New Zealand, US, UK and Australia. Since we use GDP figures, the frequency of our data is quarterly. The sample period is from 1 Jan 1997 to 31 March 2007. 


\section{Empirical Results and Their Implications}

We use the capital market approach to estimate the sensitivity of stock returns to the change of foreign exchange rates while controlling for market movements. This approach is shown in Equation 1:

$$
R_{t}=\beta_{0}+\beta_{\mathrm{m}} R_{m, t}+\beta_{X} X_{t}+\varepsilon_{\mathrm{t}}
$$

where $\mathrm{R}_{\mathrm{t}}$ is the stock return adjusted for dividend and rights issues for time $t$; $\mathrm{R}_{\mathrm{m}, \mathrm{t}}$ is the market index return for time $t ; \mathrm{X}_{\mathrm{t}}$ is the exchange rate factor for time $t$ which comes from Equation $2 ; \beta_{0}$ the intercept; $\beta_{\mathrm{m}}$ is the market exposure; $\beta_{\mathrm{x}}$ is the foreign exchange exposure; and $\varepsilon_{t}$ is the error term for time $t$.

Previous efforts to find significant exchange rate exposure have not been very successful, although most research so far has used a trade-weighted exchange rate index. Since in this study, we are interested in how overseas assets and business affect the stock performance of the four major Australian banks, we choose key currency pairs that are most relevant to our study and use them individually in the equation to avoid any offsetting exposure among foreign exchange rates. We also include all three exchange rate factors in the same equation to check how the exchange rate factors impact jointly on banks' stock performance.

Besides using key currency pairs, another adjustment to the traditional approach, following Martin and Mauer (2005), is that the exchange rate factors - are constructed to be orthogonal to the interest rate and real economic activity differentials. The orthogonal exchange rate factor is generated from $\mathrm{x}_{\mathrm{j}, \mathrm{t}}$, the residual or the unexplained part of the exchange rate which is not captured by macroeconomic variables. The model to estimate $\mathrm{x}_{\mathrm{j}, \mathrm{t}}$ is shown in Equation 2:

$$
X R T_{j, t}=\alpha_{0}+\alpha_{1} I N T_{j, t}+\alpha_{2} G D P_{j, t}+x_{j, t}
$$

where $\mathrm{XRT}_{\mathrm{j}, \mathrm{t}}$ is the value of the Australian dollar in terms of country $j$ currency at time $t ; \mathrm{INT}_{\mathrm{j}, \mathrm{t}}$ is the difference in 90-day interest rates of country $j$ and Australia at time $t ; \mathrm{GDP}_{\mathrm{j}, \mathrm{t}}$ is the ratio of the real economic activity level in country $j$ to Australia at time $t ; \mathrm{x}_{\mathrm{j}, \mathrm{t}}$ is residual exchange rate factor for country $j$ currency at time $t$; and $\alpha_{0}-\alpha_{2}$ are regression coefficients for country $j$.

The exchange rate factor used in Equation 1 is the residual exchange rate factor, $x_{j, t,}$ defined in Equation 2. Recent studies have also modified the traditional capital market model to allow an asymmetric sensitivity of returns to exchange rate risk. Miller and Reuer (1998) and Koutmos and Martin (2003) argued that stock returns likely respond differently to currency appreciation and depreciation. Koutmos and Martin (2003) found that asymmetric exposure is common in the financial sector. Since our sample firms are banks, we also seek to test an asymmetric version of the traditional capital market model, which 
includes a dummy variable to capture the potential asymmetries. When $\mathrm{X}_{\mathrm{t}}>0$, then $D_{t}=1$. The significance of $\beta_{D, x}$ shows the asymmetric exposure:

$$
R_{t}=\beta_{0}+\beta_{\mathrm{m}} R_{\mathrm{m}, \mathrm{t}}+\left(\beta_{D, X} D_{t}\right) X_{t}+\varepsilon_{t}
$$

The correlation matrix among independent variables in Equations 1-3 is shown in Table 2.1 to Table 2.3.

Table 2.1

Correlations Matrix of Independent Variables in the Study from 1 January 1997 to 31 March 2007

\begin{tabular}{lcccccc}
\hline & NZ-A & US-A & UK-A & NZ/A & US/A & UK/A \\
\hline Inter bank (NZ-A) & 1.000 & & & & & \\
Inter bank (US-A) & 0.340 & 1.000 & & & & \\
Inter bank (UK-A) & 0.496 & 0.751 & 1.000 & & & \\
Real GDP (NZ/A) & $0.266^{*}$ & -0.494 & -0.252 & 1.000 & & \\
Real GDP (US/A) & -0.147 & $0.197^{*}$ & 0.264 & -0.649 & 1.000 & \\
Real GDP (UK/A) & -0.173 & 0.064 & $0.200^{*}$ & -0.572 & 0.907 & 1.000 \\
\hline
\end{tabular}

This table shows the correlation matrix among all independent variables in Equation 2. Since there are three regressions involved in Equation 2, only the three numbers with stars are relevant to test whether there is any multicollinearity in each of the three regressions. The results show that there is no multicollinearity in each of the three regressions using Equation 2. NZ, US, UK and A stand for New Zealand, the US, the UK and Australia.

Table 2.2

Correlations Matrix of Independent Variables in the Study from 1 January 1997 to 31 March 2007

\begin{tabular}{lcccc}
\hline & ASX200 & RENZ & REUK & REUS \\
\hline ASX200 & 1.000 & & & \\
RENZ & -0.052 & 1.000 & & \\
REUK & -0.290 & 0.433 & 1.000 & \\
REUS & -0.144 & 0.336 & 0.604 & 1.000 \\
\hline
\end{tabular}

Table 2.2 shows the correlation matrix among all independent variables in Equation 1. When running Equation 1, we have four regressions for each bank. The first three regressions include the independent variables of ASX200 index returns and one of the residuals showing the foreign exchange factor. The fourth regression includes the independent variables of ASX200 index returns and all three foreign exchange residuals. RENZ, REUK and REUS stand for residuals of NZD, GBP and USD. For individual foreign exchange factor regressions, the correlations are low enough to avoid multicollinearity. However, since the correlation between Sterling Pound residual and US dollar residual is 0.6, we need to analyse the regression consisting all three foreign exchange factors with caution. 
Table 2.3

Correlations Matrix of Independent Variables in the Study from 1 January 1997 to 31 March 2007

\begin{tabular}{lrrrrrrr}
\hline & RENZ & REUK & REUS & RENZ*D & REUK*D & REUS*D & ASX200 \\
\hline RENZ & 1.000 & & & & & & \\
REUK & 0.433 & 1.000 & & & & & \\
REUS & 0.336 & 0.604 & 1.000 & & & & \\
RENZ*D & 0.858 & 0.308 & 0.254 & 1.000 & & & \\
REUK*D & 0.139 & 0.816 & 0.422 & 0.096 & 1.000 & & \\
REUS*D & 0.141 & 0.404 & 0.753 & 0.170 & 0.413 & 1.000 & \\
ASX200 & -0.052 & -0.290 & -0.144 & -0.165 & -0.412 & -0.288 & 1.000 \\
\hline
\end{tabular}

Table 2.3 shows the correlation matrix among all independent variables in Equation 3. D stands for the dummy variable showing the asymmetry effect of foreign exchange movement. Due to the very high correlations among the independent variables, we cannot use Equation 3 to test the asymmetric foreign exchange exposure on bank stock returns.

The results of the regressions using Equation 1, corrected for heteroskedasticity whenever necessary, are presented in Table 3. Before running Equation 2, we used the Dickey and Fuller (1979) unit root test to check the stationarity of the data and found the data series of foreign exchange, interest and real GDP differentials to be non-stationary, as were the residuals of the regressions. We therefore took a first difference of all variables and re-ran Equation 2 as a result of which the residuals become stationary.

The residuals from Equation 2 were then used in Equation 1 to investigate the foreign exchange effects on the bank stock returns. We ran Equation 1 for all nine banks. For each bank, there were four regressions, three regressions with single foreign exchange factors, and one with all three factors together.

This table shows the results on Equation 1: $R_{t}=\beta_{\mathrm{m}} \mathrm{R}_{\mathrm{m}, \mathrm{t}}+\beta_{\mathrm{x}} \mathrm{X}_{\mathrm{t}}+\varepsilon_{\mathrm{t}}$ where $\mathrm{Rt}$ is the stock return adjusted for dividend and right issues for time $\mathrm{t}$ of nine banks; $\mathrm{R}_{\mathrm{m}, \mathrm{t}}$ the market index return (ASX200) for time $t$; $\mathrm{X}_{\mathrm{t}}$ the exchange rate factor for time $\mathrm{t}$ which are the residuals from Equation 2. RENZ, REUK and REUS stand for residuals of NZD, GBP and USD. We run the Equation 1 for all nine banks. For each bank, there were four regressions, including three regressions with three foreign exchange factors respectively and one with all three factors together. The numbers in the parentheses are $t$-statistics. *,**, and $* * *$ denote statistical significance at the $10 \%, 5 \%$, and $1 \%$ level, respectively.

Full results are reported in Table 3, and we noted that the market index has a significant positive impact on the bank returns, except for Bank of Queensland ${ }^{6}$.

${ }^{6}$ The Bank of Queensland has been subject to some activity by large investors, which would be likely to account for the differences in its share price performance relative to the wider market. 
However, in all individual foreign exchange factor regressions, the coefficients of the foreign exchange factors are insignificant, with no difference between the major four banks and five regional banks. When putting all three foreign exchange factors together in the same regression, the New Zealand dollar factor

Table 3

Regression Results on Foreign Exchange Exposure of Australian Banks

\begin{tabular}{|c|c|c|c|c|c|c|c|}
\hline & Constant & ASX200 & RENZ & REUK & REUS & $\begin{array}{l}\text { Adjusted } \\
\text { R-square }\end{array}$ & $\begin{array}{c}\text { Durbin-Watson } \\
\text { Stat }\end{array}$ \\
\hline \multirow[t]{8}{*}{ ANZ } & 0.017 & 0.875 & -0.601 & & & 0.253 & 2.648 \\
\hline & $(1.257)$ & $(3.853)^{* * *}$ & $(-0.409)$ & & & & \\
\hline & 0.020 & 0.802 & & -0.968 & & 0.276 & 2.581 \\
\hline & $(1.432)$ & $(3.437) * * *$ & & $(-1.153)$ & & & \\
\hline & 0.017 & 0.873 & & & -0.303 & 0.251 & 2.609 \\
\hline & $(1.257)$ & $(3.802)^{* * *}$ & & & $(-0.217)$ & & \\
\hline & 0.020 & 0.795 & 0.066 & -1.340 & 0.980 & 0.241 & 2.629 \\
\hline & $(1.412)$ & $(3.318)^{* * *}$ & $(0.040)$ & $(-1.190)$ & $(0.557)$ & & \\
\hline \multirow[t]{8}{*}{ NAB } & 0.013 & 0.699 & 1.664 & & & 0.184 & 2.202 \\
\hline & $(1.025)$ & $(3.412)^{* * *}$ & $(0.942)$ & & & & \\
\hline & 0.012 & 0.741 & & 0.687 & & 0.169 & 2.333 \\
\hline & $(0.841)$ & $(3.152)^{* * *}$ & & $(0.811)$ & & & \\
\hline & 0.013 & 0.704 & & & 0.743 & 0.161 & 2.364 \\
\hline & $(0.933)$ & $(3.078)^{* * *}$ & & & $(0.533)$ & & \\
\hline & 0.012 & 0.724 & 1.422 & 0.339 & -0.037 & 0.140 & 2.239 \\
\hline & $(0.865)$ & $(3.013)^{* * *}$ & $(0.858)$ & $(0.300)$ & $(-0.021)$ & & \\
\hline \multirow[t]{8}{*}{ CBA } & 0.023 & 0.775 & 1.006 & & & 0.247 & 2.399 \\
\hline & $(1.857)^{*}$ & $(3.807)^{* * *}$ & $(0.764)$ & & & & \\
\hline & 0.022 & 0.803 & & 0.452 & & 0.242 & 2.460 \\
\hline & $(1.756)^{*}$ & $(3.769)^{* * *}$ & & $(0.589)$ & & & \\
\hline & 0.024 & 0.747 & & & -0.828 & 0.244 & 2.370 \\
\hline & $(1.920)^{*}$ & $(3.630)^{* * *}$ & & & $(-0.660)$ & & \\
\hline & 0.022 & 0.802 & 1.019 & 0.941 & -2.067 & 0.244 & 2.344 \\
\hline & $(1.758)^{*}$ & $(3.751)^{* * *}$ & $(0.691)$ & $(0.938)$ & $(-1.317)$ & & \\
\hline \multirow[t]{8}{*}{ WBC } & 0.010 & 0.977 & 1.861 & & & 0.398 & 2.312 \\
\hline & $(0.875)$ & $(5.125)^{* * *}$ & $(1.510)$ & & & & \\
\hline & 0.012 & 0.900 & & -0.768 & & 0.380 & 2.290 \\
\hline & $(1.059)$ & $(4.457)^{* * *}$ & & $(-1.057)$ & & & \\
\hline & 0.012 & 0.930 & & & -1.350 & 0.383 & 2.208 \\
\hline & $(0.990)$ & $(4.773)^{* * *}$ & & & $(-1.136)$ & & \\
\hline & 0.014 & 0.868 & 3.136 & -1.106 & -1.267 & 0.441 & 2.287 \\
\hline & $(1.204)$ & $(4.509) * * *$ & $(2.361)^{* *}$ & $(-1.223)$ & $(-0.897)$ & & \\
\hline
\end{tabular}


Table 3

Regression Results on Foreign Exchange Exposure of Australian Banks

\begin{tabular}{|c|c|c|c|c|c|c|c|}
\hline & Constant & ASX200 & RENZ & REUK & REUS & $\begin{array}{l}\text { Adjusted } \\
\text { R-square }\end{array}$ & $\begin{array}{c}\text { Durbin- } \\
\text { Watson Stat }\end{array}$ \\
\hline \multirow[t]{8}{*}{$\mathrm{ADB}$} & 0.019 & 0.588 & 1.986 & & & 0.166 & 2.020 \\
\hline & (1.483) & $(2.824)^{* * * *}$ & $(1.476)$ & & & & \\
\hline & 0.020 & 0.554 & & -0.221 & & 0.118 & 1.946 \\
\hline & $(2.076)^{* * *}$ & $(2.483)^{* *}$ & & $(-0.299)$ & & & \\
\hline & 0.019 & 0.582 & & & 0.435 & 0.119 & 1.984 \\
\hline & $(1.984)^{*}$ & $(2.714)^{* * * *}$ & & & $(0.399)$ & & \\
\hline & 0.021 & 0.518 & 2.592 & -1.142 & 0.727 & 0.148 & 1.966 \\
\hline & $(1.622)$ & $(2.350)^{* *}$ & $(1.706)^{*}$ & $(-1.104)$ & $(0.449)$ & & \\
\hline \multirow[t]{8}{*}{ BOQ } & 0.026 & 0.315 & 1.496 & & & 0.014 & 2.017 \\
\hline & $(1.829)^{*}$ & $(1.320)$ & $(0.971)$ & & & & \\
\hline & 0.026 & 0.307 & & 0.060 & & -0.011 & 2.110 \\
\hline & $(1.800)^{*}$ & (1.221) & & $(0.067)$ & & & \\
\hline & 0.027 & 0.284 & & & -0.761 & -0.004 & 2.148 \\
\hline & $(1.874)^{*}$ & (1.172) & & & $(-0.514)$ & & \\
\hline & 0.027 & 0.292 & 1.933 & 0.103 & -1.474 & -0.020 & 2.049 \\
\hline & $(1.824)^{*}$ & $(1.148)$ & $(1.104)$ & $(0.086)$ & $(-0.791)$ & & \\
\hline \multirow[t]{8}{*}{ SGB } & 0.027 & 0.656 & 1.130 & & & 0.221 & 2.018 \\
\hline & $(2.447)^{* * *}$ & $(3.537) * * *$ & $(0.942)$ & & & & \\
\hline & 0.027 & 0.657 & & 0.122 & & 0.203 & 1.979 \\
\hline & $(2.387)^{* *}$ & $(3.355)^{* * *}$ & & $(0.173)$ & & & \\
\hline & 0.027 & 0.664 & & & 0.719 & 0.211 & 2.002 \\
\hline & $(2.402)^{* *}$ & $(3.523)^{* * *}$ & & & $(0.625)$ & & \\
\hline & 0.028 & 0.638 & 1.208 & -0.474 & 0.798 & 0.185 & 2.026 \\
\hline & $(2.411)^{* *}$ & $(3.206)^{* * *}$ & $(0.881)$ & $(-0.508)$ & $(0.547)$ & & \\
\hline \multirow[t]{8}{*}{ BEN } & 0.019 & 0.699 & 0.680 & & & 0.066 & 2.035 \\
\hline & $(0.988)$ & $(2.171)^{* *}$ & $(0.327)$ & & & & \\
\hline & 0.016 & 0.786 & & 1.147 & & 0.086 & 2.102 \\
\hline & $(0.844)$ & $(2.364)^{* *}$ & & $(0.959)$ & & & \\
\hline & 0.019 & 0.700 & & & 0.303 & 0.064 & 2.098 \\
\hline & $(0.982)$ & $(2.154)^{* * *}$ & & & $(0.153)$ & & \\
\hline & 0.016 & 0.794 & -0.110 & 1.626 & -1.245 & 0.041 & 2.123 \\
\hline & $(0.810)$ & $(2.323)^{* *}$ & $(-0.047)$ & $(1.013)$ & $(-0.496)$ & & \\
\hline \multirow[t]{8}{*}{ SUN } & 0.027 & 0.769 & 1.884 & & & 0.211 & 2.028 \\
\hline & $(1.987)^{*}$ & $(3.349)^{* * *}$ & $(1.268)$ & & & & \\
\hline & 0.027 & 0.770 & & 0.201 & & 0.178 & 2.086 \\
\hline & $(1.921)^{*}$ & $(3.148)^{* * *}$ & & $(0.228)$ & & & \\
\hline & 0.027 & 0.783 & & & 1.225 & 0.192 & 2.170 \\
\hline & $(1.928)^{*}$ & $(3.339)^{* * * *}$ & & & $(0.856)$ & & \\
\hline & 0.029 & 0.738 & 2.012 & -0.808 & 1.374 & 0.182 & 2.076 \\
\hline & $(1.996)^{*}$ & $(3.011)^{* * * *}$ & $(1.190)$ & $(-0.702)$ & $(0.764)$ & & \\
\hline
\end{tabular}


has some impact on Adelaide Bank and Westpac. The P-values for the two coefficients are $9.69 \%$ and $2.39 \%$ respectively. ${ }^{7}$ Moreover, because we have run a total of 36 regressions, chance is likely to cause some to appear to be significant, even if there were no valid relationships in reality. ${ }^{8}$

The adjusted $\mathrm{R}^{2}$ statistics for the regressions reported in Table 3 are, except for Westpac, all below 0.3, and in Westpac's case the highest adjusted $\mathrm{R} 2$ reported was 0.441 . A significant proportion of the variability in banks' stock returns is thus not explained, and may thus be attributable to interest rate levels, bank-performance specific factors, etc. Because there is a corpus of literature (Samuelson, 1945; Flannery and James, 1984) that has looked at the impact of interest rates on banks' share prices, we tried including interest rate returns as an additional explanatory variable in our regression analyses (Equation 1). Interest rate factors were not in general found to be significant, and there was no clear improvement in the explanatory power of our new regressions.

As a further test for the robustness of our findings, we ran regressions looking at all four major banks together as a panel, firstly looking at the currency effects individually, and then together. We also ran these models with interest rate returns as an additional explanatory variable. Once again no significant relationships were found.

A comment on an earlier version of this paper suggested that we should be looking at the raw exchange rate changes as well as the residual exchange rate factors. As a further check on our results, we therefore undertook regressions using only the raw exchange rates, but once again failed to find any significant results for anything other than the market index.

We also sought to use Equation 3 to test the asymmetric exposure of the three currencies on the banks' stock returns. However, when we explored the correlations among the independent variables, we found that each foreign exchange residual and the product of the residual and the dummy variable were highly correlated (Table 2.3). We were therefore not able to use Equation 3 to further our study.

\section{Conclusions}

The findings of our research are surprising. There is no evidence that the market reacts to the changing value of bank assets held outside of Australia for the four major Australian banks. The basic theoretical proposition that we sought to explore is the portfolio theory of the international expansion of banks,

\footnotetext{
${ }^{7} \mathrm{We}$ were concerned at the possibility of multicollinearity, in view of the relatively high correlations between the GBP and USD exchange rate factors in particular, but values of the Variance Inflation Factors were low, suggesting that this was not a problem in practice.

${ }^{8}$ On the other hand, until 2003, Westpac was the bank with the largest proportion of its assets in New Zealand, although its figures were not much larger than for ANZ. Adelaide Bank has not at any stage had any New Zealand business.
} 
which suggests that banks expand internationally to diversify their risks, and to reduce their relative exposure to their home country markets. It also entails a view of banks as a portfolio of businesses operating in different countries, and that banks' market values should reflect the international composition of their portfolios, with share values rising (and positive stock returns) as the home country's currency weakened against those of the foreign countries in which the bank invested.

In presenting our research hypothesis, however, we identified a number of potential outcomes, not dependent on the portfolio theory of the international expansion of banks. We suggested that banks might not hedge their currency exposures, and that markets are efficient, in which case a strengthening of that currency relative to the Australian dollar would result in an increase in the bank's relative share price (reflected in positive stock returns). Alternatively, if banks hedged their foreign currency positions, we would expect no relationship to be evident. The third possibility is that share markets fail to adequately reflect information about the currencies to which the banks are exposed through their asset portfolios. ${ }^{9}$

Review of the banks' reported risk management policies and the commentary provided by the Reserve Bank of Australia both suggest that banks do not hedge their structural foreign exchange exposures arising from their international business operations. This would therefore suggest that markets are not efficiently pricing the shares of Australian banks. Another possible explanation is that investors are not primarily focused on asset values, but rather on profit streams. Insofar as banks are hedging current profits (as they suggest in their policies for management of foreign exchange risk), investors may perceive banks as protected against exchange rate changes, and share prices would thus not be sensitive to these changes.

Alternatively, exchange rate changes may be perceived as relatively short term, with the currency likely to revert to a mean in due course. This might apply particularly in the case of the New Zealand dollar which is a commoditybased currency similar to the Australian dollar. Another possibility would be that investors might desire the currency exposure consequent upon investing in the major banks, meaning that they would be largely unfazed by exchange rate changes.

It may be noted that the period from 1997 to 2007 (as covered by this research) was a positive one for the Australian economy in general, and for the banks as well. Banks have also enjoyed positive outcomes in New Zealand. Different results might be found if there were to be some less benign economic experience. It would also be interesting to look at banks from other countries which have undertaken significant international expansion. Martin and Mauer (2005) have applied an approach similar to this to look at a group of United

${ }^{9}$ The question then arises as to whether this might also be the case for other classes of firms with net foreign exchange exposures. 
States banks, but it would also be possible (and meaningful) to look at banks from Canada, the United Kingdom, Spain and a number of other countries whose banks have expanded into different currency areas.

Author information: Submitting author, Professor Martin Young, Department of Economics and Finance, Massey University, Private Bag 11-222, Palmerston North, New Zealand, Phone: +(64-6)-3505799 Ext 2482, Fax: +(64-6)-3505651, Email: M.Young@massey.ac.nz.

\section{References}

Becker, C., Debelle, and G., Fabbro, D. (2005, December). Australia's foreign currency exposure and hedging practices. Reserve Bank of Australia Bulletin, 1-8.

Carew, E. (1997). Westpac: The bank that broke the bank. Sydney: Doubleday.

Cho, K.R. (1985). Multinational banks: Their identities and determinants. Ann Arbor: UMI Research Press.

Dickey, D.A., and Fuller, W.A. (1979). Distribution of the estimators for autoregressive time series with a unit root. Journal of the American Statistical Association, 74 427-431.

Flannery, M.J., and James, C.M. (1984). The effect of interest rate changes on the common stock returns of financial institutions. Journal of Finance, 39,(4) 1141-1153.

Goldberg, L.G., and Kabir, R. (2002). The stock market performance of the central banks of Belgium and Japan. Journal of Economics and Business, 54, 137-152.

Grosse, R., and Goldberg, L.G. (1991). Foreign bank activity in the United States: An analysis by country of origin. Journal of Banking and Finance, 15, 1093-1112.

Hultman, C.W., and McGee, L.R. (1989). Factors affecting the foreign banking presence in the U.S. Journal of Banking and Finance, 13, 383-396.

Koutmos, G., and Martin, A.D. (2003). Asymmetric exchange rate exposure: theory and evidence. Journal of International Money and Finance, 22, 365-383.

Martin, A.D., and Mauer, L.J. (2005). A note on common methods used to estimate foreign exchange exposure. Journal of International Financial Markets, Institutions and Money 15, 125-140.

Miller, K.D., and Reuer, J.J. (1998). Asymmetric corporate exposures to foreign exchange rate changes. Strategic Management Journal, 19, 1183-1191.

Moshirian, F., and Pham, T. (1999). Cost of capital and Australia's banking investment abroad. Applied Financial Economics, 9, 295-303.

Moshirian, F. (2001). International investment in financial services. Journal of Banking and Finance, 25, 317-337. 
Robinson, D. (1990, August). Aussie charmers nab the profits. Euromoney, 4445.

Samuelson, P.A. (1945, March). The effect of interest rate increases on the banking system. American Economic Review, 16-27.

Staff. (2000, August). Foreign exchange exposures of Australian banks. Reserve Bank of Australia Bulletin, 43-49.

Staff. (2002, August). Australia's foreign currency exposure and hedging practices. Reserve Bank of Australia Bulletin, 56-60.

Tripe, D. and Matthews, C., (2003). The international expansion of Australian banks. In Lőnnborg, M; Olsson, M.; Rafferty, M. \& Nalson, I (Eds.), Money and finance in transition (pp. 155-180). Huddinge, Sweden: Sődertőrns hőgskola.

Wilkins, S. (2003). The international diversification of Australian banks. In Lőnnborg, M: Olsson, M.; Rafferty, M. \& Nalson, I (Eds.), Money and finance in transition (pp. 181-196). Huddinge, Sweden: Sődertőrns hőgskola.

Williams, B. (1997). Positive theories of multinational banking: Eclectic theory versus internalisation theory. Journal of Economic Surveys, 11(1), 71100. 